\title{
Devonian macroinvertebrates from the State of Tocantins: occurrence history and new findings
}

\author{
Macroinvertebrados devonianos do estado de Tocantins: \\ histórico de ocorrências e novos achados
}

\section{Macroinvertebrados devónicos del estado de Tocantins: historia de ocurrencia y nuevos hallazgos}

\author{
Victor Rodrigues Ribeiro \\ https:/ / orcid.org/0000-0002-6290-5599 \\ victor.r.ribeiro@unespbr \\ Universidade Estadual Paulista, \\ UNESP, Bauru, SP, Brazil \\ Felipe Nascimento Sousa \\ https:/ / orcid.org/0000-0002-9801-0324 \\ fn.sousa@unespbr \\ Universidade Estadual Paulista, \\ UNESP, Bauru, SP, Brazil
}

Geovane Augusto Gaia

https:/ / orcid.org/0000-0003-0262-7256

geovane.gaia@unespcom

Universidade Estadual Paulista,

UNESP, Bauru, SP, Brazil

\author{
Fábio Augusto Carbonaro \\ https://orcid.org/0000-0003-3614-253X \\ fabiocarbonaro@gmail.com \\ Universidade Estadual Paulista, \\ UNESP, Bauru, SP, Brazil \\ Sandro Marcelo Scheffler \\ https:/ / orcid.org/0000-0002-6965-4550 \\ schefflersm1@gmail.com \\ Museu Nacional, Universidade Federal do Rio de Janeiro, \\ UFRJ, Rio de Janeiro, RJ, Brazil
}

\author{
Renato Pirani Ghilardi \\ https:/ / orcid.org/0000-0003-0410-8011 \\ renato.ghilardi@unespbr \\ Universidade Estadual Paulista, \\ UNESP, Bauru, SP, Brazil
}

\begin{abstract}
The state of Tocantins has been the subject of several paleontological researches in the past; however, the Devonian fossils have recently been poorly investigated. This paper expands the knowledge about Devonian in the state of Tocantins, presenting a bibliographic review and adding new fossiliferous discoveries. During fieldwork, brachiopods (Australocoelia, Australospirifer, Derbyina, infaunal lingulids, Orbiculoidea, Tropidoleptus carinatus, Schuchertella), cnidarians (Conularia quichua), crinoids (Exaesiodiscus dimerocrinosus, Laudonomphalus, Monstrocrinus), mollusks (Platyceras, Nuculites, Palaeoneilo, Sanguinolites), and plants remains (Spongiophyton lenticularis) were found in different sedimentary facies of the Pimenteira Formation.
\end{abstract}

Keywords: Middle Devonian, South America, Parnaíba Basin, Fossil, Pimenteira Formation. 
Resumo: O estado do Tocantins foi alvo de várias pesquisas paleontológicas no passado; no entanto, recentemente os fósseis do Devoniano foram pouco investigados. Este artigo amplia o conhecimento sobre o Devoniano no estado do Tocantins, apresentando uma revisão bibliográfica e agregando novas descobertas fossilíferas. Durante trabalhos de campo, braquiópodes (Australocoelia, Australospirifer, Derbyina, lingulídeos infaunais, Orbiculoidea, Tropidoleptus carinatus, Schuchertella), cnidários (Conularia quichua), crinoides (Exaesiodiscus dimerocrinosus, Laudonomphalus, Monstrocrinus), moluscos (Platyceras, Nuculites, Palaeoneilo, Sanguinolites) e restos de plantas (Spongiophyton lenticularis) foram encontrados em diferentes fácies sedimentares da Formação Pimenteira.

Palavras-chave: Devoniano Médio, América do Sul, Bacia do Parnaíba, Fóssil, Formação Pimenteira.

Resumen: El estado de Tocantins ha sido el objetivo de varias investigaciones paleontológicas en el pasado; sin embargo, los fósiles del Devónico se han investigado poco recientemente. Este artículo amplía el conocimiento sobre el Devónico en el estado de Tocantins, presentando una revisión bibliográfica y agregando nuevos descubrimientos fosilíferos. Durante el trabajo de campo, se encontraron braquiópodos (Australocoelia, Australospirifer, Derbyina, lingúlidos infaunales, Orbiculoidea, Tropidoleptus carinatus, Schuchertella), cnidarios (Conularia quichua), crinoideos (Exaesiodiscus dimerocrinosus, Laudonomphalus, Monstrocrinus), moluscos (Platyceras, Nuculites, Palaeoneilo, Sanguinolites) y restos vegetales (Spongiophyton lenticularis) en diferentes facies sedimentarias de la Formación Pimenteira.

Palabras clave: Devónico medio, América del Sur, Cuenca del Parnaíba, Fósil, Formación Pimenteira.

\section{INTRODUCTION}

The Parnaíba Basin is located in the northeast of South America in an area of approximately 600 thousand $\mathrm{km}^{2}$, with rocks ranging from Silurian to Cretaceous (Góes \& Feijó, 1994). Brazilian Devonian lithotypes are found only in the easter and western borders of the basin, at Piauí and Tocantins states. Most of the paleontological studies are associated with the eastern portion while in the western margin studies are still scarce.

The Devonian fossils from Piauí are well represented by brachiopods, mollusks, arthropods, cnidarians, echinoderms, ichnofossils, tentaculitids, plants and fishes (Kegel, 1953; Barbosa, Ramos, Gomes \& Helmbold,1966; Ramos, 1967; Assis \& Fernandes, 1980; Ferreira \& Fernandes, 1983; Góes \& Feijó, 1994; Santos \& Carvalho, 2004; Vaz, Rezende, Wanderley Filho \& Travassos, 2007; Queiroz, Gama Jr \& Pires, 2013). On the other hand, in Tocantins state few studies mention brachiopods, tentaculitids, cnidarians, molluscs, echinoderms, and plants (Ramos, 1967; Melo, 1988; Gama Jr., 2008; Scheffler et al., 2011; Queiroz, Gama Jr \& Pires, 2013), as well as palynomorphs, spores, chitinozoan, and acritarchs (Lima \& Leite, 1978; Grahn, Melo, \& Loboziak, 2006), microfitoplancton (Trindade \& Carvalho, 2018) and ichnofossils (Assis \& Fernandes, 1980; Ferreira \& Fernandes, 1983).

Remarkably, few papers discuss the Devonian fossils in just over half a century of paleontological studies in Tocantins. To enhance the knowledge about Devonian 
fossils from South America, our main goal is to present a bibliographic review and increase information about fossiliferous occurrences.

\section{GEOLOGICAL BACKGROUND}

The Parnaíba Basin is located on the South American platform and it has a basement composed of magmatic and metamorphic rocks. The sedimentary rocks were deposited during different geological events along the Silurian to the Cretaceous. However, events during the Triassic - Jurassic and early Cretaceous resulted in the occurrence of igneous rocks (Góes \& Feijó, 1994). The outcrops are located in the states of Maranhão, Piauí, Tocantins, Pará, Ceará, and Bahia (Fig. 1).

The Devonian rocks were first described by Small (1914) in the surrounding areas of Pimenteiras, Piauí state. On that occasion, the rocks were individualized as reddish sandstones and schists, called Pimenteiras Formation. After that, Kegel (1953) attributed the Eifelian age to the basal rocks (Itaim Formation), overlapped by the Pimenteiras and Cabeças Formation, of Givetian age. Finally, Grahn, Melo \& Loboziak (2006) performed microfossiliferous analyzes in the central and western Devonian of the Parnaíba basin, resulting in ages from the late Eifelian to late Frasnian for the Pimenteiras Formation. In general, the Pimenteiras Formation is characterized by rocks that were deposited during significant marine transgressions and regressions, covering marine platforms with strong storm influences (Santos \& Carvalho, 2004).

Figure 1: Area of occurrence of the Parnaíba Basin.

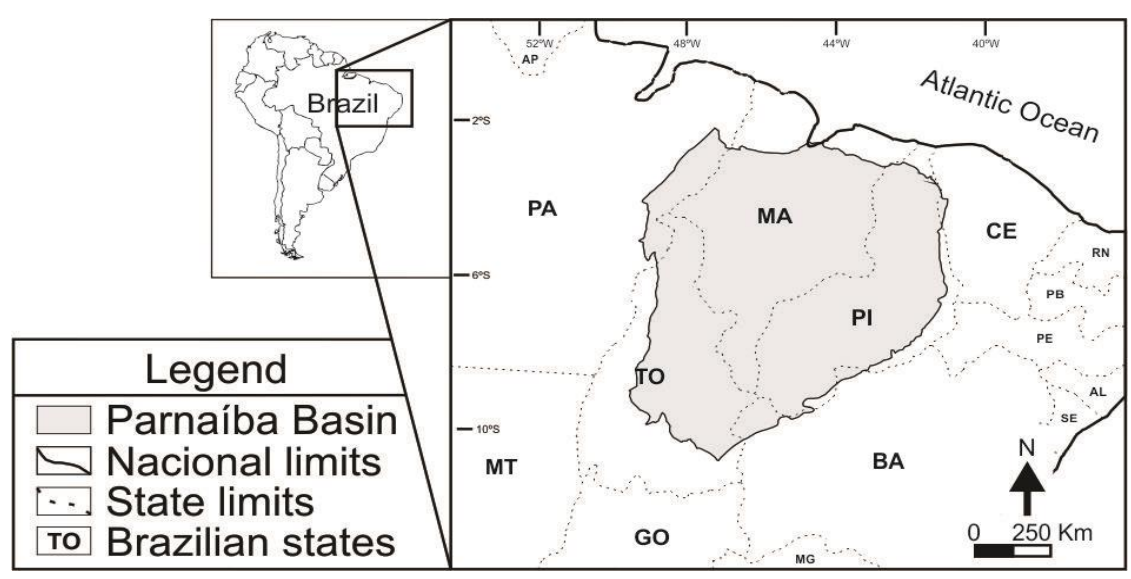

Source: Adapted from Melo (1988).

\section{PALEONTOLOGICAL BACKGROUND OF TOCANTINS STATE}

The first Tocantins Devonian fossil were recorded by Barbosa et al. (1966). On the occasion, the authors mention brachiopods Chonetoidea Bronn, 1862, Spiriferoidea King, 1846, and Australocoelia Boucot \& Gill, 1956, from the Pimenteiras Formation, on the right 
bank of the Araguaia river. It was in the old village of Santo Antoninho, current city of Ananás (Santos \& Carvalho, 2004). Later, Ramos (1967) recorded in the city of Tocantínia the genera Spirifer Sowerby, 1818, Derbyina Clarke, 1913, Orbiculoidea D'Orbigny, 1847, Chonetes Fischer de Waldheim, 1830, Australocoelia and Lingula Bruguiére, 1797, the thallophyte Spongiophyton Kräusel, 1954, the cnidarian Conularia Sowerby, 1820, including tentaculitids.

Ramos \& Barbosa (1967) reported the occurrence of Spirifer sp, Derbyina sp and Orbiculoidea? sp close to the Rio dos Mangues; Tentaculites sp, Orbiculoidea sp, Crinoids, and a bivalve in Tocantínia; Orbiculoidea sp, Conularia sp and Australocoelia? sp in Lajeado; and Spongiophyton sp on rocks from the Pimenteira Formation, in the state of Tocantins. Portela et al. (1976) also reported Spongiophyton sp in Tocantínia and Novo Acordo. Lima \& Leite (1978) found acritarchs as Maranhites brasiliensis Brito, 1965, Duvernaysphaera sp, Umbellaphaeridiune sp, and Veryachium sp, also in the Pimenteira Formation, as well as Ancyrospora sp, Nikintirosporites sp, Biharisporites sp, and Knoxisporites sp, with a predominance of Hymenozotriletes sp, and Acarethotriletes sp.

One of the first reports of ichnofossils in the state of Tocantins was made by Brito (1977). On the occasion, the author described Asteriacites sp as associated with ferruginous sandstones in Tocantínia. Assis \& Fernandes (1980) and Ferreira \& Fernandes (1983) also described ichnofossils (Bifungites sp, Cruziana sp, Rusophycus sp, Guilielmites sp, Neonereites? $\mathrm{sp}$, Palaeophycus sp), and coprolites in black shales from Pimenteira Formation, next to the city of Miranorte.

After a long period without publications about the Devonian of Tocantins, Loboziak, Caputo \& Melo (2000) improved the scientific information about Pimenteira Formation presenting a biostratigraphic analyses using miospore from different localities (Paraíso do Tocantins, Palmas, Miranorte, Miracema do Tocantins, Tocantínia, Pedro Afonso, Itacajá, Tupiratins, and Colinas do Tocantins). Later, Grahn, Melo \& Loboziak (2006) presented biostratigraphic analyzes of chitinozoan from the Itaim and Pimenteira formations.

Corrêa, Agostinho, Fernandes \& Vieira (2004) reviewed the ichnofossils previously published by Ferreira \& Fernandes (1983), updating its systematic proposal. In this new perspective, the authors proposed the names Bifungites isp, Nereites cf. N. missouriensis Weller, 1899, Rusophycus polonica Seilacher, 1970, Trichophycus isp, and "Guilielmites" sp. So, Fernandes \& Fonseca (2005) reclassified the ichnospecies described by Brito (1977) and the older Asteriacites isp became Asteriacites stelliforme Miller \& Dyer, 1878.

Gama Jr. (2008) collected fossils near the city of Palmas (Estância Cantilena and Fazenda Encantada II), where he identified brachiopods as Montsenetes carolinae Fonseca, 2004, Australocoelia palmata Morris \& Sharpe, 1846, Delthyridoidea Phillips, 1841, Mucrospirifer pedroanus Rathbun, 1874, Amphigenia cf. A. elongate Vanuxem, 1842, and Tropidoleptus carinatus Conrad, 1839, and crinoids, gastropods, Conularia and tentaculites in the Itaim and Pimenteira Formations. According to the author, this was the first occurrence of $M$. carolinae, A. palmata, and M. pedroanus in the lower part of the Pimenteira Formation.

Scheffler (2010) presented some crinoids from the Pimenteira Formation, such as Monstrocrinus sp B, Exaesiodiscus sp A, E. sp B, Laudonomphalus aff. L. tuberosus, L. sp A, L. sp B, L. sp C, L. sp D and Marettocrinus? sp A. A year later, Scheffler, Dias-Da-Silva, Gama 
Júnior, Da Fonseca \& Fernandes (2011) described for the first time crinoids in the western border of the Parnaíba Basin, in the surrounding area of Palmas. Monstrocrinus incognitus Scheffler et al., 2011, Rhodocrinitidae Roemer, 185), Exaesiodiscus dimerocrinosus Scheffler et al., 2011, Exaesiodiscidae Moore \& Jeffords, 1968, and Laudonomphalus aff. L. tuberosus Yeltysheva, 1961. Flucticharacidae Moore \& Jeffords, 1968 were found in the Estância Cantilena, and Fazenda Encantada II.

Queiroz, Gama Jr \& Pires (2013) performed fieldworks on Rio das Balsas, Santa Teresa city, recording the first occurrence of brachiopods, crinoids, and bivalves in this region. In the locality were found Australocoelia palmata, Australospirifer iheringi Kayser, 1900, and Tropidoleptus carinatus in the Pimenteira Formation. In the same year, the first brachiopod Orthida Schuchert \& Cooper, 1932 was recorded by Silva \& Candeiro (2013), in the central region of Tocantins, between the cities of Aparecida do Rio Negro and Palmas (Table 1).

The most recent papers have a palynological approach. Drilling holes were studied around the cities of Aparecida do Rio Negro, Novo Acordo, and Lagoa de Tocantins, to remake the paleoenvironment. The wells intersect the Itaim, Pimenteira and Cabeças formations, where chitinozoan, prasinophytes, acritarchs and miospore were recorded, indicating ages from the limit Pragian-Emsian to Famennian (Trindade, Carvalho \& Borghi, 2015; Trindade \& Carvalho, 2018).

Table 1: Macrofossils of Devonian invertebrates and plants from TocantinsState.

\begin{tabular}{|c|c|c|c|}
\hline PHYLUM / CLASS & TAXON & LOCATION & AUTHOR \\
\hline \multirow[t]{14}{*}{ Brachiopoda } & Australocoelia sp & $\begin{array}{l}\text { Santo Antoninho and } \\
\text { Santa Teresa } \\
\end{array}$ & Barbosa et al. (1966) \\
\hline & Australocoelia palmata & Palmas & \begin{tabular}{|l} 
Gama Jr. (2008) \\
Queiroz, Gama Jr \& Pires (2013)
\end{tabular} \\
\hline & Montsenetes carolinae & Palmas & Gama Jr. (2008) \\
\hline & Amphigenia cf. A. elongata & Palmas & Gama Jr. (2008) \\
\hline & Mucrospirifer pedroanus & Palmas & Gama Jr. (2008) \\
\hline & Australospirifer iheringi & Santa Teresa & Queiroz, Gama Jr \& Pires (2013) \\
\hline & Centroneliidae & Palmas & Gama Jr. (2008) \\
\hline & Amphigenia sp & Santo Antoninho & $\begin{array}{l}\text { Barbosa et al. (1966), Ramos (1967), } \\
\text { Gama Jr. (2008) }\end{array}$ \\
\hline & Delthyridoidea g. A sp 1 & Palmas & Gama Jr. (2008) \\
\hline & Derbyina sp & Tocantínia & Ramos (1967) \\
\hline & Lingula sp & Tocantínia & Ramos (1967) \\
\hline & Orbiculoidea sp & Tocantínia & Ramos (1967) \\
\hline & Orthida indet. & $\begin{array}{l}\text { Aparecida do Rio } \\
\text { Negro and Palmas }\end{array}$ & Silva \& Candeiro (2013) \\
\hline & Tropidoleptus carinatus & $\begin{array}{l}\text { Palmas and Santa } \\
\text { Teresa }\end{array}$ & \begin{tabular}{|l} 
Gama Jr. (2008) \\
Queiroz, Gama Jr \& Pires. (2013) \\
\end{tabular} \\
\hline Cnidaria & Conulariidae & Tocantínia & Ramos (1967), Gama Jr. (2008) \\
\hline \multirow[t]{4}{*}{ Crinoidea } & undetermined & Palmas & Gama Jr. (2008) Scheffler (2010) \\
\hline & Exaesiodiscus dimerocrinosus & Palmas & Scheffler et al. (2011) \\
\hline & $\begin{array}{l}\text { Laudonomphalus aff. } L . \\
\text { tuberosus }\end{array}$ & Palmas & Scheffler et al. (2011) \\
\hline & Monstrocrinus incognitus & Palmas & Scheffler et al. (2011) \\
\hline
\end{tabular}


conclusão

\begin{tabular}{l|l|l|l}
\hline PHYLUM / CLASS & TAXON & LOCATION & AUTHOR \\
\hline Gastropoda & Undetermined & Palmas & Gama Jr. (2008) \\
\hline Bivalvia & undetermined & Tocantínia & Ramos \& Barbosa (1967) \\
\hline & undetermined & Santa Teresa & Queiroz, Gama Jr \& Pires (2013) \\
\hline Incertae sedis (Plantae) & Spongiophyton sp & $\begin{array}{l}\text { Tocantínia and } \\
\text { Novo Acordo }\end{array}$ & Ramos \& Barbosa (1967) \\
\hline
\end{tabular}

\section{VISITED OUTCROPS}

According to the literature there are several fossiliferous outcrops in the state of Tocantins (Kegel, 1953; Barbosa et al.,1966; Ramos, 1967; Assis \& Fernandes, 1980; Ferreira \& Fernandes, 1983; Góes \& Feijó, 1994; Santos \& Carvalho, 2004; Vaz et al., 2007; Queiroz, Gama Jr \& Pires, 2013). Those could be found in areas close to the cities of Aparecida do Rio Negro, Barrolândia, Bom Jesus do Tocantins, Miracema do Tocantins, Miranorte, Monte Carmo, Novo Acordo, Palmas, Pedro Afonso, and Taquaruçu do Porto.

We have found fossils in 15 outcrops during the fieldwork. Notes comprehended geographic coordinates, outcropping rocks description, and stratigraphic inferences as well as stratigraphic profiles. However, we present just seven outcrops (Fig. 2) once they had the most well-preserved fossils (Table 2).

Figure 2: Outcrop location map where the fossils were collected.
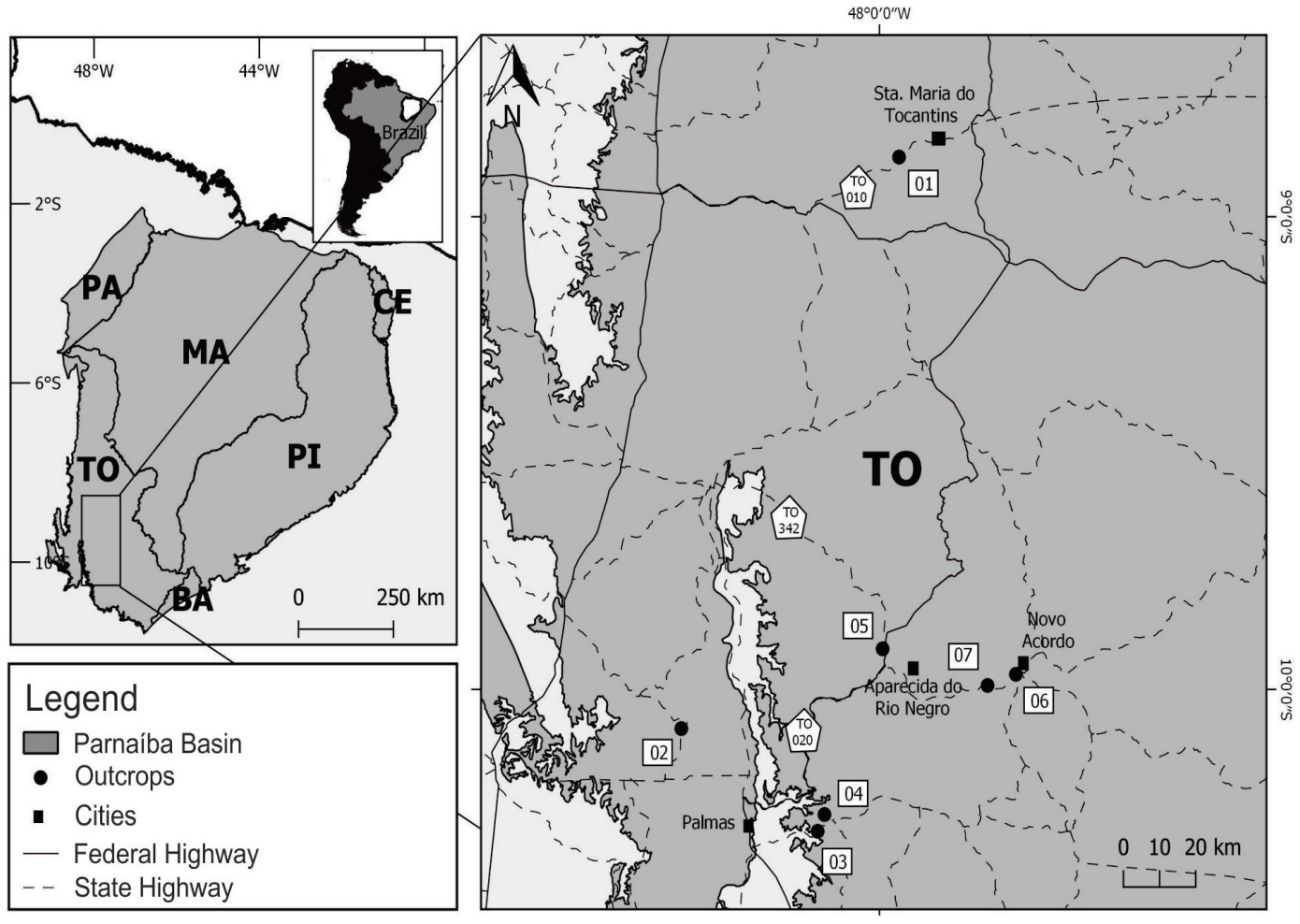
All fossils were collected in rocks of the Pimenteira Formation. This one is characterized as alternating sequences of reddish to yellowish sandstones, siltstones, and purplish to grayish sandstone with varying thickness. The sandstones granulometry range from medium to fine and sedimentary structures has wavy marks, hummocky, crossed stratifications, and incipient wavy marks. On the other hand, in the siltstones are common the plane-parallel stratifications, the wavy marks are rarely found, and the alterations with very fine yellowish sandstone are usually noticed.

Table 2: Outcrops with fossiliferous material presented in this paper.

\begin{tabular}{l|l|l|l}
\hline SPOT & LATITUDE & LONGITUDE & LOCALITY \\
\hline 01 & $08^{\circ} 52^{\prime} 25,61^{\prime \prime} \mathrm{S}$ & $47^{\circ} 57^{\prime} 17,80^{\prime \prime} \mathrm{W}$ & Margins of highway TO-010 \\
\hline 02 & $10^{\circ} 04^{\prime} 58,80^{\prime \prime} \mathrm{S}$ & $48^{\circ} 27^{\prime} 15,80^{\prime \prime} \mathrm{W}$ & Margins of highway TO-348 \\
\hline 03 & $10^{\circ} 18^{\prime} 01,09^{\prime \prime} \mathrm{S}$ & $48^{\circ} 08^{\prime} 30,16^{\prime \prime} \mathrm{W}$ & Mirante de Taquaruçu \\
\hline 04 & $10^{\circ} 15^{\prime} 53,50^{\prime \prime} \mathrm{S}$ & $48^{\circ} 07^{\prime} 33,50^{\prime \prime} \mathrm{W}$ & Fazenda Encantada II \\
\hline 05 & $09^{\circ} 54^{\prime} 51,20^{\prime \prime} \mathrm{S}$ & $47^{\circ} 59^{\prime} 33,40^{\prime \prime} \mathrm{W}$ & Margins of highway BR-010 \\
\hline 06 & $09^{\circ} 58^{\prime} 05,20^{\prime \prime} \mathrm{S}$ & $47^{\circ} 41^{\prime} 13,10^{\prime \prime} \mathrm{W}$ & Margins of highway TO-020 \\
\hline
\end{tabular}

The paleoenvironmental diagenetic processes of the Pimenteira Formation in the studied area present three facies associations. The first one (type A) includes rhythmic alternations of abundant siltstones, clayey, and very fine sandstones with plane-parallel stratifications, deposited by decantation in a low-energy marine environment. The second one (type B) combines finely laminated sandstones and siltstones, with parallel flat stratifications and wavy marks, deposited in a transitional environment. Finally, the third association of facies (type $\mathrm{C}$ ) is characterized by sandstones with cross-layered hummocky stratifications, deposited by the influence of storm waves on a platform. The fieldwork, as well as the physiological distinctions, drove to a compound section for the Pimenteira Formation showed in Figure 3. 
Figure 3: Composite section elaborated from the visited outcrops, where it is possible to notice the distinguished facies. Being a: hummocky cross-stratification; b: rocky pavement containing a great diversity of crinoids; c: large hummocky cross-bedding; d: alternation of siltstone and sandstones of facies B association; e: wavy marks and plane-parallel stratifications in sandstones and lutites; f: physiognomy of type A facies associations.
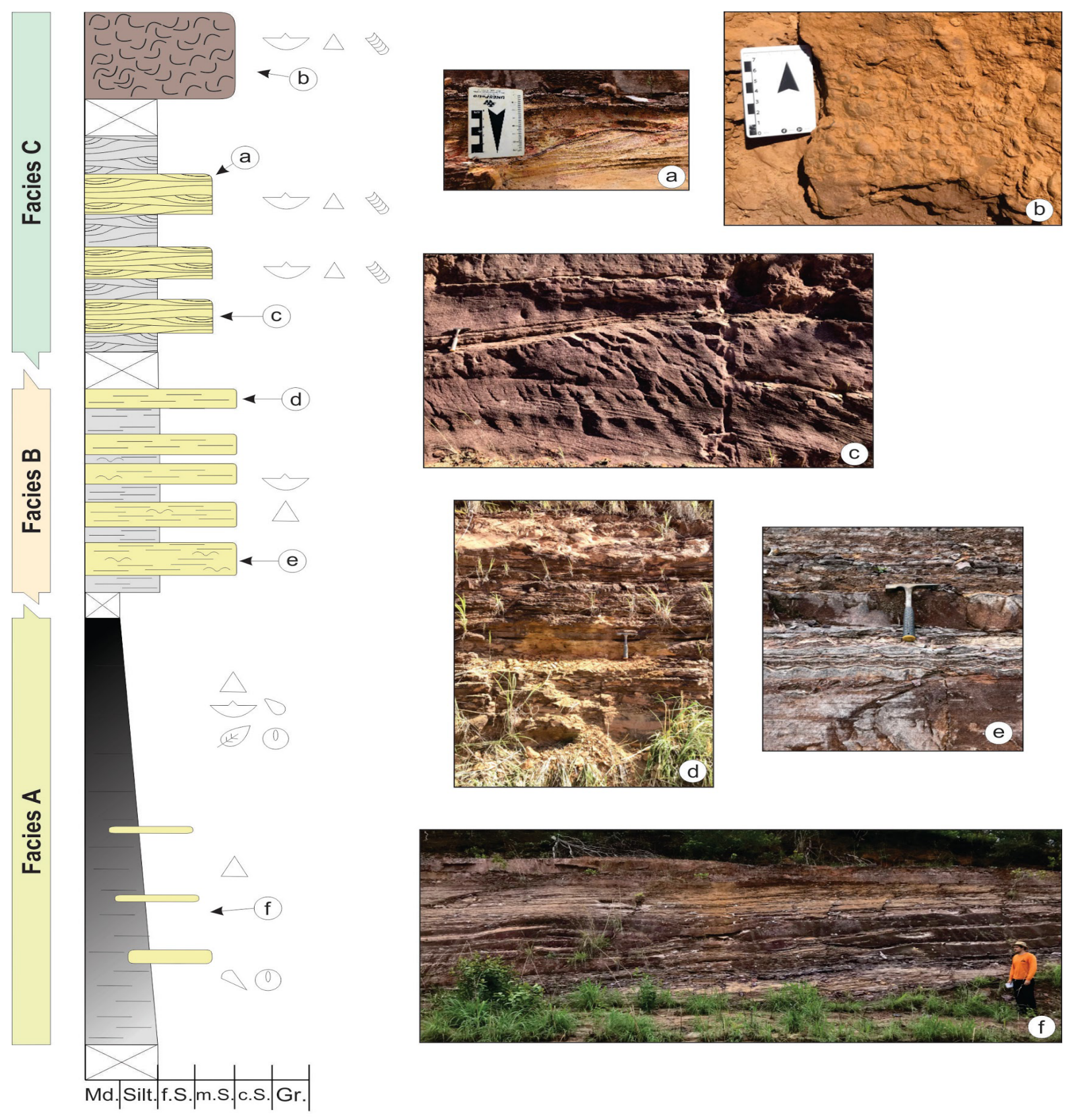

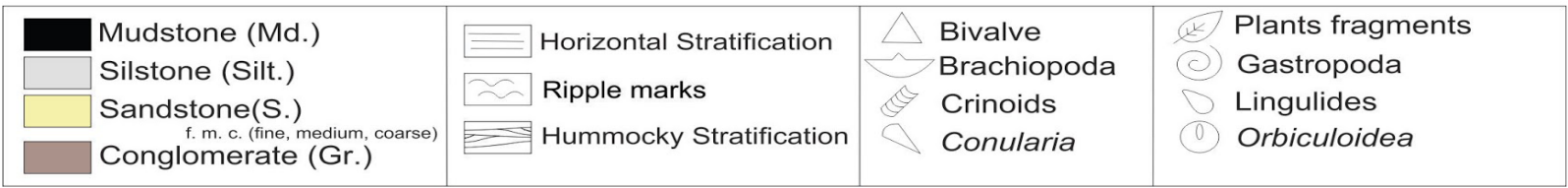




\section{COLLECTED FOSSILS}

Fossils collected in the most diverse localities were brachiopods, cnidarians, crinoids, mollusks, and fragments of plants.

Brachiopods could be identified as Australocoelia sp, Australospirifer? sp, Schuchertella? sp, Derbyina? sp, Tropidoleptus carinatus, infaunal lingulids, and Orbiculoidea sp (Fig. 4). It is worth mentioning that Barbosa et al. (1966), Gama Jr. (2008), and Queiroz, Gama Jr \& Pires (2013) have already described some specimens of Australocoelia sp, Australospirifer sp, and Tropidoleptus carinatus in Tocantins. However, for the first time, the genus Schuchertella? was recorded in the western portion of the Basin.

Figure 4: Brachiopods collected in Tocantins: a (peduncular valve of Australospirifer? sp, CCLP 1250); b (brachial valve of Derbyina? sp, CCLP 1239); c (brachial valve of Schuchertella? sp, CCLP 1251); d1 (front view, CCLP 1201.2), d2 (dorsal view, CCLP 1201.2), d3 (posterior view, CCLP 1201.2 of Tropidoleptus carinatus); e (photograph taken in the field); f (peduncular valve, CCLP 1240), g (brachial valve of Orbiculoidea sp, CCLP 1246); h (CCLP 1228), i (CCLP 1229, infaunal lingulids); j (brachial valve, CCLP 1195.3), k (peduncular valve of Australocoelia sp, CCLP 1256). Scale: $1 \mathrm{~cm}$.
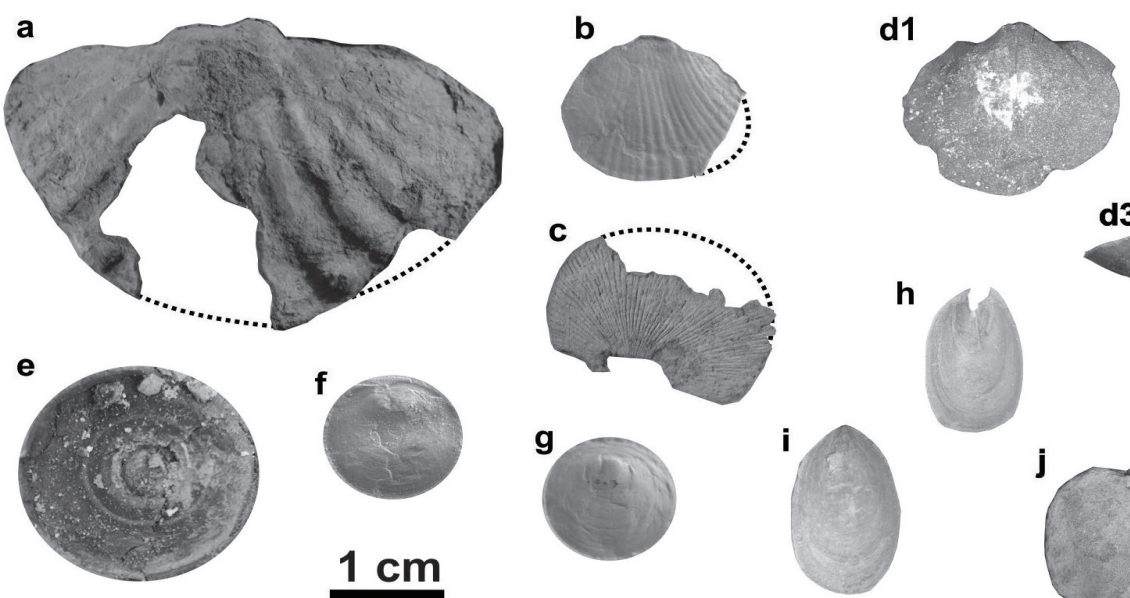

d2
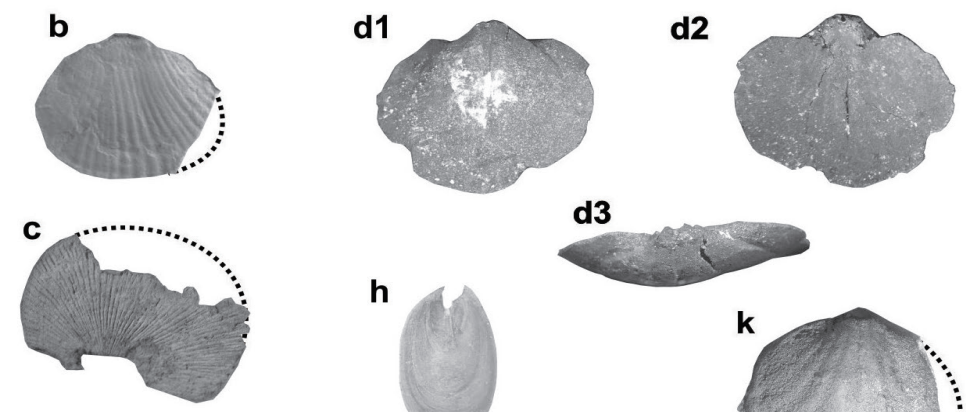

\section{d3}
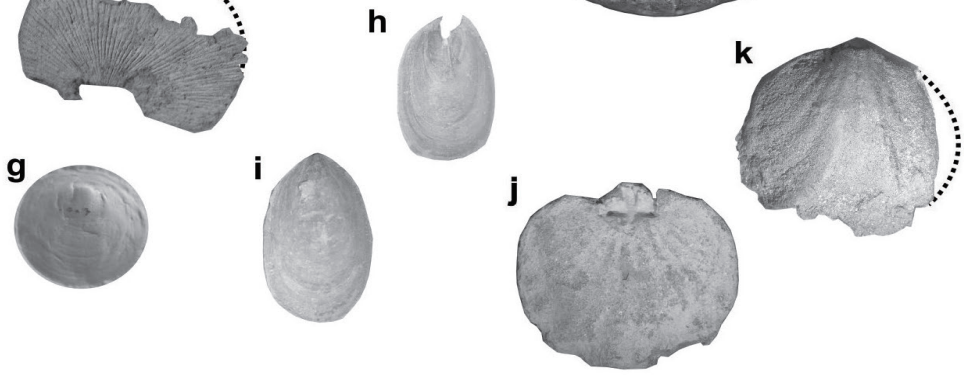

Considering the facies associated with the brachiopods, it is possible to notice that Derbyina? sp, Orbiculoidea sp, and the lingulids were found exclusive in type A facies, from a low-energy marine environment. Furthermore, Tropidoleptus carinatus and Australocoelia sp were identified in facies type $\mathrm{C}$, whose disposition is related to storm waves on marine platforms. Finally, Australospirifer? sp and Schuchertella? sp were found in transitional facies B.

Ramos (1967) and Gama Jr. (2008) reported the first occurrence of conulariids in the Devonian of Tocantins, next to the city of Tocantínia, north of Palmas. Fossils of Conularia quichua Ulrich, 1890 (Fig. 5) were found between the cities of Pedro Afonso and Santa Maria do Tocantins, associated with type A facies. 
Figure 5: Conularia quichua: a (theca with a full face, CCLP 1145); b (two faces of the opening region, CCLP 1138); c (faces with the middle and opening regions, CCLP 1143). Scale: $1 \mathrm{~cm}$.

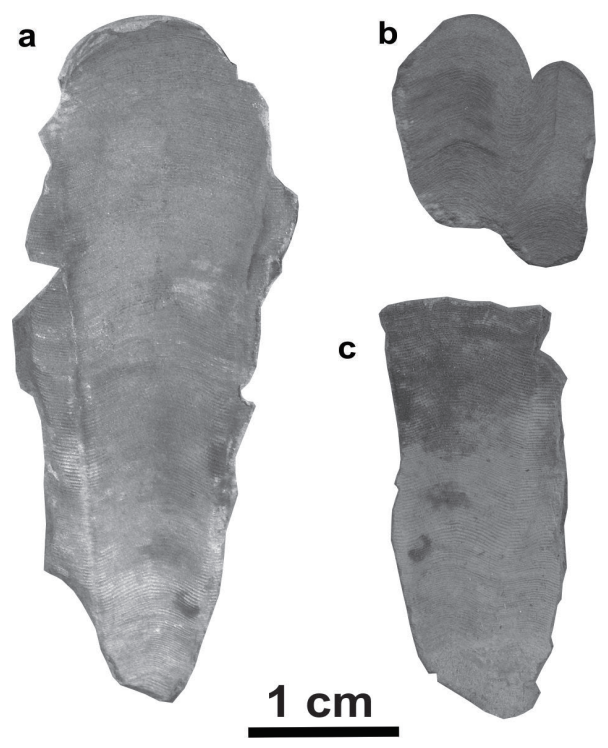

Crinoids were found in type $\mathrm{C}$ high energy facies, identified as Exaesiodiscus dimerocrinosus, Laudonomphalus sp A, Laudonomphalus sp C and Monstrocrinus sp (Fig. 6). A calycinal plaque with a thorn was also found, which resembles those of the genus Achantocrinus Roemer, 1850. Gama Jr. (2008) had already identified some crinoids for the western portion of the Parnaíba Basin. However, Scheffler et al. (2011) identified and described these organisms taxonomically. Noteworthy is the presence of a column of another species of pedunculated echinoderm, which has not yet been described for formation. The specimen is anchored in the disjointed column of E. dimerocrinosus, which demonstrates the permanence of these columns on the seabed before the final burial, being used as a substrate for fixation.

Figure 6: Crinoids found during fieldworks: a1 (CCLP 1193.3), a2 (CCLP 1193.4), b1 (CCLP 1194.3),

b2 (CCLP 1194.5, Exaesiodiscus dimerocrinosus); c (calycinal plaque with spine, similar to the genus Acanthocrinus, CCLP 1193.6); d1, d2 (Laudonomphalus sp A, CCLP 1194.1), e1, e2 (Laudonomphalus sp C, CCLP 1194.2); f (CCLP 1193.1) e g (Monstrocrinus sp, CCLP 1193.2). Scale: $1 \mathrm{~cm}$
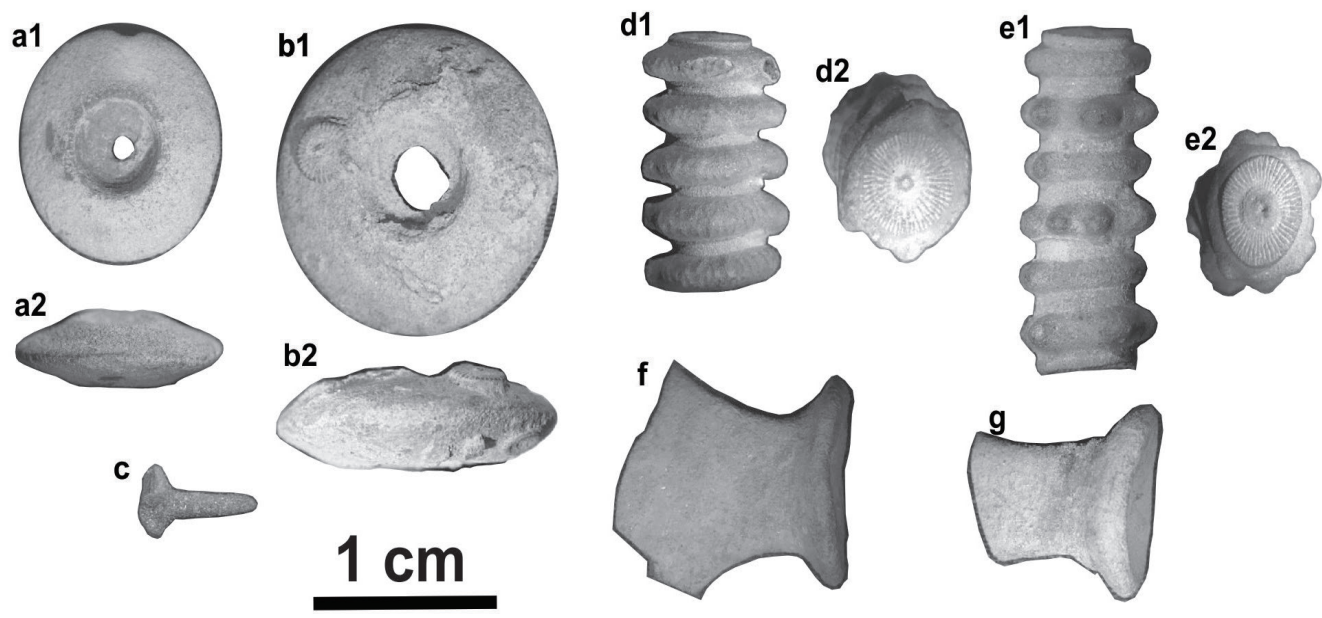
Few studies have addressed the occurrence of mollusks in Devonian rocks in the state of Tocantins. Bivalves were found in different localities and facies associations. In low energy facies (type A) were found Nuculites? Conrad, 1841 and Sanguinolites M'Coy, 1844, in addition to an unidentified bivalve. On the other hand, in type $C$ facies, the gastropod Platyceras sp was found. Finally, a specimen of Palaeoneilo Hall \& Whitfield, 1869 was found in type B facies (Fig. 7).

Figure 7: Mollusks found during fieldworks: a (right valve in lateral view of Palaeoneilo sp, CCLP 1253); b (right valve in lateral view of Nuculites? sp, CCLP 1247); c (articulated valves in a side view of unidentified bivalve, CCLP 1197); d (right valve in lateral view of Sanguinolites sp, CCLP 1196); e (e1 dorsal view; e2 - side view of Platyceras sp, CCLP 1202); f (f1 - dorsal view; f2 - basal view; f3 - side view of Platyceras sp, CCLP 1255). Scale: $1 \mathrm{~cm}$.

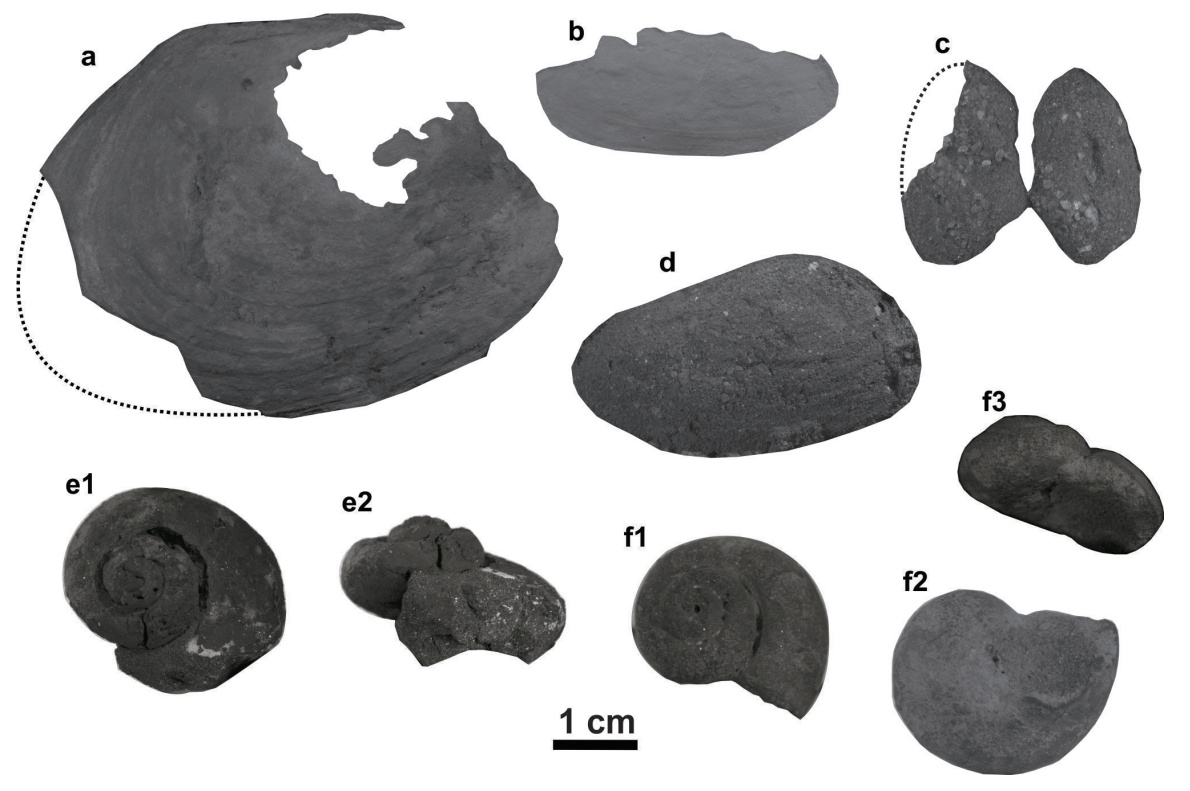

Some examples of Devonian plants were found in the vicinity of Tocantínia and Novo Acordo, where Ramos (1967) and Portela et al. (1976) indicated occurrences of Spongiophyton sp The occurrence of this taxon was restricted to the species Spongiophyton lenticularis (Barbosa) Kräusel 1954, found in low energy facies (Fig.8).

Figure 8: Plant sampled, Spongiophyton lenticularis, CCLP 1173. Scale: 5,0 mm.

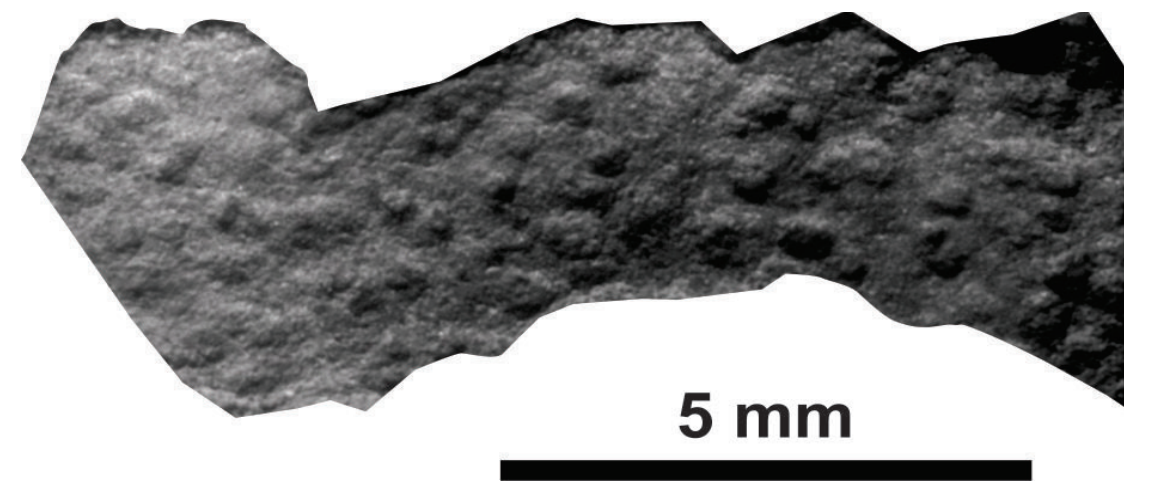


Among the fossils found in the Tocantins, Australocoelia sp was found in locality number 4, Derbyina? sp in the locality 7, Australospirifer? sp in 5, lingulids in locality 7, Orbiculoidea sp at 1, 6 and 7, Tropidoleptus carinatus at locality 4 and 5, and finally Schuchertella? sp at location number 5. Cnidaria, which at first were reported only in the vicinity of Tocantínia, were found in abundance at the locality named 1, identified as Conularia quichua. The crinoids (Exaesiodiscus dimerocrinosus, Laudonomphalus sp A, L. sp C, Achantocrinus? sp and Monstrocrinus sp) were only found in one location, named here number 4, associated with species of brachiopods and gastropods. Lastly, bivalves were found in different locations. Nuculites? sp in locality number 7, Palaeoneilo sp at number 5, Sanguinolites sp and unidentified molluscs in location 2. The plants (Spongiophyton lenticularis) were collected in locality number 3 and 7 (Table 3).

Table 3: Fossils collected during fieldworks and presented on this paper.

\begin{tabular}{|c|c|c|c|}
\hline PHYLUM / CLASS & TAXON & COLLECTED SPOT & FACIES \\
\hline \multirow{10}{*}{ Brachiopoda } & Australocoelia sp & 4 & C \\
\hline & Australospirifer? $\mathrm{sp}$ & 5 & $\mathrm{~B}$ \\
\hline & Derbyina? sp & 7 & A \\
\hline & infaunal lingulids & 7 & A \\
\hline & \multirow{3}{*}{ Orbiculoidea sp } & 1 & A \\
\hline & & 6 & A \\
\hline & & 7 & A \\
\hline & Tropidoleptus carinatus & 4 & $\mathrm{C}$ \\
\hline & & 5 & $\mathrm{C}$ \\
\hline & Schuchertella? sp & 5 & B \\
\hline Cnidaria & Conularia quichua & 1 & $\mathrm{~A}$ \\
\hline \multirow{4}{*}{ Crinoidea } & Exaesiodiscus dimerocrinosus & 4 & C \\
\hline & Laudonomphalus sp A & 4 & C \\
\hline & Laudonomphalus sp C & 4 & $\mathrm{C}$ \\
\hline & Monstrocrinus sp & 4 & C \\
\hline Gastropoda & Platyceras sp & 4 & $\mathrm{C}$ \\
\hline \multirow{4}{*}{ Bivalvia } & Nuculites? sp & 7 & A \\
\hline & Sanguinolites sp & 2 & A \\
\hline & Palaeoneilo sp & 5 & B \\
\hline & Undetermined & 2 & $\mathrm{~A}$ \\
\hline Incertae sedis (Plantae) & Spongiophyton lenticularis & 7 & A \\
\hline
\end{tabular}

\section{FINAL REMARKS}

Among the several macrofossils presented in this paper, brachiopods have the highest taxonomic diversity - it compounds approximately $40 \%$ of fossils found during fieldworks in the state of Tocantins. Crinoids and bivalves correspond to $20 \%$ of taxonomic diversity each, followed by 6,7\% of gastropoda, cnidaria, and plants (Fig. 9). 
Figure 9: Taxonomic diversity of Devonian fossils from Tocantins.

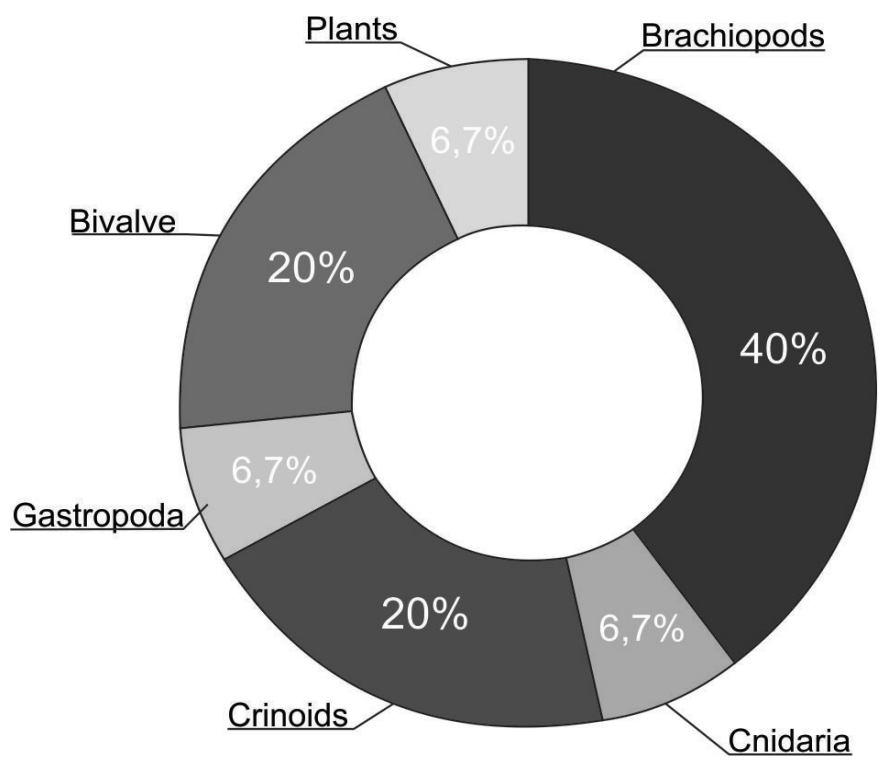

Paleontological studies about Devonian invertebrates in Brazil are less common when compared to other areas of Paleontology. This paper aims to gather more information about the South American Devonian fossils, as well as highlight the new fossiliferous occurrences in the western portion of the Parnaiba Basin. It is noticeable an increasing number of fossiliferous occurrences in the state of Tocantins, comparing to the previous taxonomic diversity data. The new occurrences of brachiopods (Schuchertella? sp), cnidaria (Conularia quichua), mollusks (Platyceras sp, Nuculites? sp, Palaeoneilo sp and Sanguinolites $\mathrm{sp}$ ), and plants (Spongiophyton lenticularis) highlight the importance of the Parnaíba Basin for South American Devonian studies and point how poor the current knowledge of its western border is. In general, the Parnaíba Basin hosted great variety of fossils during the Devonian age, with great importance for the South American platform. The outcrops on the eastern edge of the basin have been explored since 1940, however, in the western side, just a little has been made. This work revives Devonian paleontological studies with macrofossils in the state of Tocantins, as well as enhancing the existing research in the region.

Taking into consideration the depositional facies (types A, B, and C), the taxa Derbyina?, infaunal lingulids, Orbiculoidea, Conularia quichua, Sanguinolites, Nuculites?, and Spongiophyton were found exclusively in facies with low energy, type A. The taxa Australocoelia, Tropidoleptus carinatus, Exaesiodiscus dimerocrinosus, Laudonomphalus, Monstrocrinus, and Platyceras were found in high energy depositional facies type C. Finally, taxa Australospirifer?, Schuchertella?, and Palaeoneilo were found in the transitional facies type B (Fig. 10).

The occurrences of Tropidoleptus carinatus in the Devonian of Tocantins can infer the Eifelian-Frasnian age. This Brachiopoda has its origin in the European basins during the Lochkovian, and just during the Middle Devonian, it gets a great widely paleogeographic distribution, because of Devonian climatic changes. 
Figure 10: Facies association (A, B, and C) with their corresponded fossiliferous occurrences.

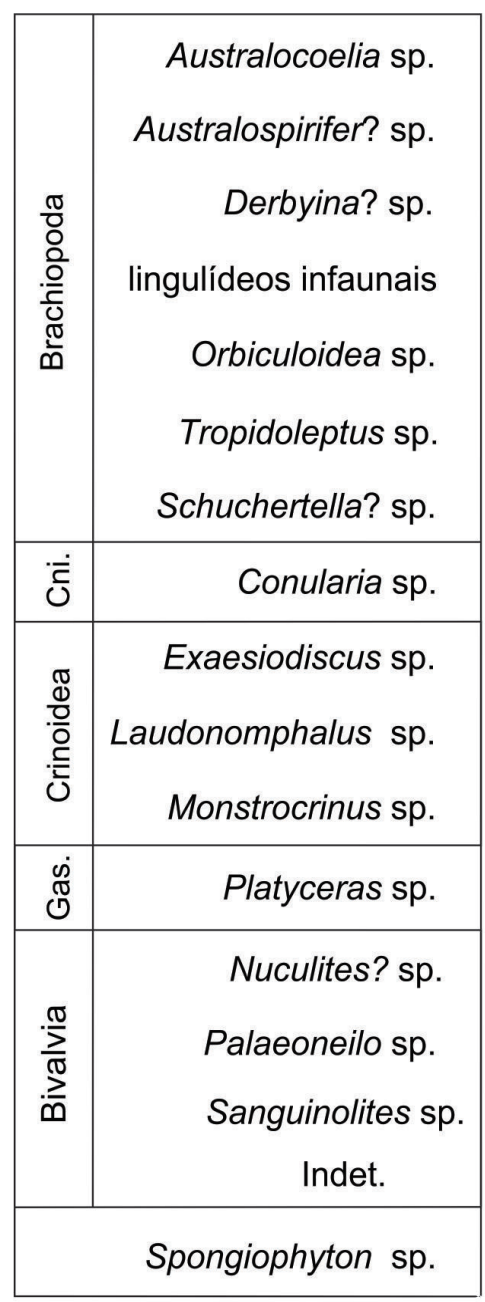
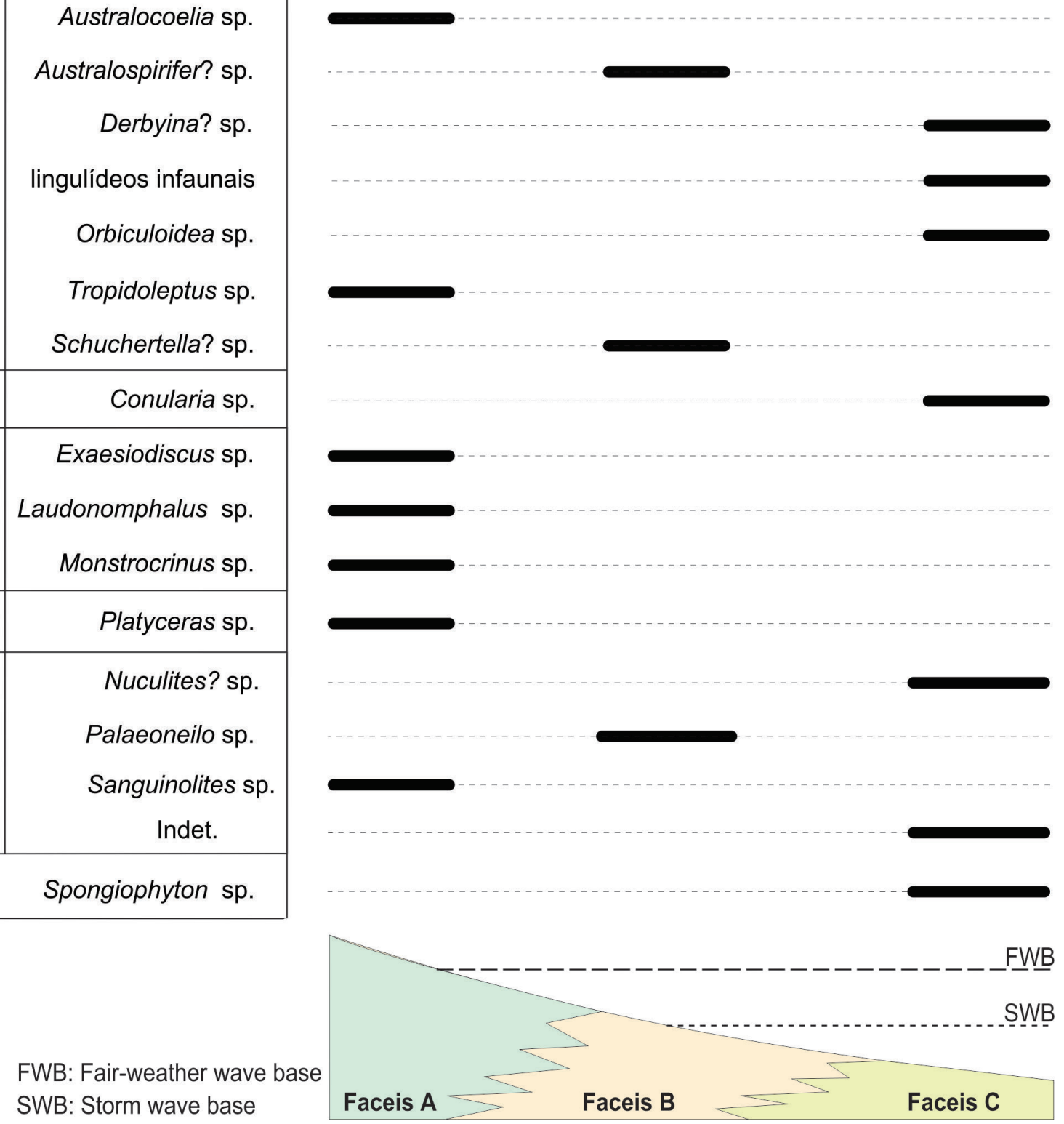

\section{ACKNOWLEDGMENTS}

To São Paulo Research Foundation (FAPESP, process 2016/18275-4) for supporting the fieldworks; to Rio de Janeiro Research Foundation (FAPERJ, process E-26/200.110/2019; Emergencial Support to National Museum) for the financial support; to CAPES for the Master's Scholarship to Geovane Gaia, and Ph.D. Scholarship to Felipe Sousa and Victor Ribeiro; to José Mendes Gama Jr. and Beatriz Melo for helping in fieldwork. 


\section{REFERENCES}

Assis, J.F.P., \& Fernandes, A.C.S. (1980). A ocorrência de Bifungites Desio, 1940 na Formação Pimenteiras, Devoniano da Bacia do Maranhão. Anais Da Academia Brasileira de Ciência, 52, 335-338.

Barbosa, O., Ramos, J.R.A., Gomes, F.A., \& Helmbold, R. (1966). Geologia Estratigráfica, Estrutural e Econômica da Área do Projeto Araguaia. Rio de Janeiro: DNPM. (Monografia 19).

Brito, I.M. (1977). Ocorrência de Bióglifos no Devoniano Inferior do município de Tocantínia, Goiás. Anais da Academia Brasileira de Ciência, 49(3), 461-464.

Corrêa, L.M.S.A., Agostinho, S., Fernandes, A.C.S., \& Vieira, P.M. (2004). Icnofósseis da Formação Pimenteira (Devoniano da Bacia do Parnaíba), município de Miranorte, Estado do Tocantins, Brasil. Arquivos do Museu Nacional, 62(3), 283-291.

Fernandes, A.C.S., \& Fonseca, V.M.M. (2005). A contribuição de Ignacio Aureliano Machado Brito à icnologia brasileira. Arquivos do Museu Nacional, 63(3), 619-624.

Ferreira, C.S., \& Fernandes, A.C.S. (1983). Notícias sobre alguns icnofósseis da Formação Pimenteira, Devoniano no Estado de Goiás. Anais da Academia Brasileira de Ciência, 55(1), 140.

Gama Jr., J.M. (2008). Braquiópodes da Formação Pimenteiras (Devoniano Médio/Superior), na região sudoeste da Bacia do Parnaíba, município de Palmas, Estado do Tocantins, Brasil. Dissertação de Mestrado em Geociências, Universidade Federal de Brasília, UFB, Brasília, Brasil.

Góes, A.M.O., \& Feijó, F.J. (1994). Bacia de Parnaiba. Boletim de Geociências da Petrobras, 8(1), 57-68.

Grahn, Y., Melo, J.H.G., \& Loboziak, S. (2006). Integrated Middle and Late Devonian miospore and chitinozoan zonation of the Parnaíba Basin, Brazil: An update. Revista Brasileira de Paleontologia, 9(3), 283294. https:// doi.org/10.4072/rbp.2006.3.03

Kegel, W. (1953). Contribuição para o estudo do Devoniano da Bacia do Parnaíba. Recife: DNPM. (Boletim 141).

Lima, E.A.M., \& Leite, J.F. (1978). Projeto estudo global dos recursos minerais da Bacia Sedimentar do Parnaíba: integração geológico-metalogenética. Recife: DNPM.

Loboziak, S., Caputo, M.V., \& Melo, J.H.G. (2000). Middle Devonian-Tournaisian miospore biostratigraphy in the southwestern outcrop belt of the Parnaíba Basin, north-central Brazil. Revue de Micropaléontologie, 43(4), 301-318.

Melo, J.H.G. (1988). The Malvinokaffric Realm in the Devonian of Brazil. In. McMillan, N.J.; Embry, A.F. \& D. J. Glass (Eds.). Devonian of the World: Proceedings of the 2nd International Symposium on the Devonian System, Canadian Society of Petroleum Geologists. pp. 669-703. https:// doi.org/10.1016/j.jafrearsci.2019.103549

Portela, A.C.P., Marchetto, C.M.L., Santos, E L., Meneguesso, G., Stein, J.H., Costa, L. A. M., ... \& Silva, W.G. (1976). Projeto leste do Tocantins/oeste do Rio São Francisco: relatório final. DNPM. Geologia, Prospecções e Aerofotogrametria.

Queiroz, J.P., Gama Jr, J.M., \& Pires, E.F. (2013). Ocorrência de braquiópodes fósseis no entorno do Rio Balsas, município de Santa Teresa, Estado do Tocantins, em estratos da Formação Pimenteira, Devoniano da bacia do Parnaíba. Brazilian Geographical Journal, 4(1), 191-212.

Ramos, J.R.A., \& Barbosa, R.A. (1967). Geologia e petrografia de Porto Nacional a Miracema do Norte, Rio Tocantins. Atas Do Simpósio Sobre a Biota Amazônica, 1, 387-400.

Ramos, J.R.A. (1967). Estratigrafia da região Xingu-Tocantinia. Atas do Simpósio sobre a Biota Amazônica, 1, 373-386.

Santos, M.E.C.M., \& Carvalho, M.S.S. (2004). Paleontologia das Bacias do Parnaíba, Grajaú e São Luís. In Programa Levantamentos Geológicos Básicos do Brasil.

Scheffler, S.M. (2010). Crinóides e Blastóides do Devoniano Brasileiro. Tese de doutorado em Geociências. Universidade Federal do Rio de Janeiro, UFRJ, Rio de Janeiro, RJ, Brasil. 
Scheffler, S.M., Dias-Da-Silva, S., Gama Júnior, J.M., Da Fonseca, V.M.M., \& Fernandes, A.C.S. (2011). Middle Devonian Crinoids from the Parnaiba Basin (Pimenteira Formation, Tocantins State, Brazil). Journal of Paleontology, 85(6), 1188-1198. https:// doi.org/10.1666/10-142.1

Silva, K.R., \& Candeiro, C.R.A. (2013). Primer Registro de Braquiópodos en el Devónico de la Formación Pimenteiras (Cuenca del Parnaíba) en la Región de Palmas, Provincia de Tocantins, Brasil. Biota Amazônia, 3(2), 74-78. https://doi.org/10.18561/2179-5746/ biotaamazonia.v3n2p74-78

Small, H.L. (1914). Geologia e supprimento de agua subterranea no Piauhy e parte do Ceará. Rio de Janeiro: Inspectoria de Obras Contra as Seccas.

Trindade, V.S.F. \& Carvalho, M.A. (2018). Paleoenvironment reconstruction of Parnaíba Basin (north, Brazil) using indicator species analysis (IndVal) of Devonian microphytoplankton. Marine Micropaleontology, 140(January), 69-80. https://doi.org/10.1016/j.marmicro.2018.02.003

Trindade, V.S.F., Carvalho, M.A., \& Borghi, L. (2015). Palynofacies patterns of the Devonian of the Parnaíba Basin, Brazil: Paleoenvironmental implications. Journal of South American Earth Sciences, 62, 164-175. https:// doi.org/10.1016/j.jsames.2015.06.001

Vaz, P.T., Rezende, N.G.A.M., Wanderley Filho, J.R., \& Travassos, W.A.S. (2007). Bacia do Parnaíba. Boletim de Geociencias da Petrobras, 15(2), 253-263.

Data de submissão: 21/maio/2021

Data de aceite: $01 /$ set./2021 